\title{
Obituary
}

The Right Hon. Lord Moynihan, K.C.M.G., C.B. T ORD MOYNIHAN died on September 7 at his 1 home, Carr Manor, Leeds, in his seventy-first year. His fame was world-wide, and great gifts with which he was endowed made him the greatest surgeon of the day both in Great Britain and abroad. His father was Captain Moynihan of the 8th Foot, who gained the Victoria Cross in the Crimean War. Ten years later, on October 2, 1865, Berkeley Moynihan, his only son, was born at Malta. He was educated at the Royal Naval School and entered the Leeds Medical School for his professional training. He took his M.B. at the University of London in 1887 and the fellowship of the Royal College of Surgeons of England in 1890. After graduation he started teach. ing anatomy in the Leeds Medical School ; later he was appointed assistant surgeon to the Leeds General Infirmary and then in due course surgeon and consulting surgeon and professor of surgery in the University of Leeds.

Moynihan's success as a teacher and reputation as a surgeon brought him early a lucrative practice in the north of England, and he was rewarded with a knighthood in 1912. During the Great War he was appointed consulting surgeon to the Northern Command, and later, consulting surgeon to the British Expeditionary Force, with the rank of MajorGeneral A.M.S. He was made K.C.M.G. in 1918 and a baronet in 1922. In 1929 he was created Baron Moynihan of Leeds, the only surgeon with the exception of Lister to receive a peerage. At the Royal College of Surgeons he passed successively through all the offices and held the post of president for six years (1926-32), a longer time than any of his predecessors.

Many qualities contributed to make Moynihan the man he was. Physically he was strong, rarely ailing and possessed of abundant energy and vitality. Cheerful in disposition and willing to please, he was eager to be liked. Perhaps this was the Irish element coming out in him. It is to his credit that though he loved to please, he was just as pleasant to an omnibus conductor as he was to a titled patient. Mentally he was alert, quick-witted and ready to seize a new idea, make it his own and improve on it. As a speaker he was pre-eminent. His addresses and speeches, of which he made many, though carefully prepared, were delivered in faultless manner without a note, and their charm and persuasiveness were enhanced by a full melodious voice.

These attributes, great as they were, would not have led to Moynihan's high position if it had not been for his great powers as a surgeon. In the early years of this century his fame was growing, and a visit to Leeds to see Moynihan at work became a routine for surgeons visiting England from abroad and especially for surgeons from the United States, amongst whom he had many friends and with whom his reputation stood high.
The reason for this high reputation may be ascribed in the first instance to technical skill. Moynihan was a master in technique and it was a joy to watch him at work. There was nothing of the slapdash, cutand-thrust method of the pre-Listerine surgeon. Instead infinite patience and infinite gentleness, by which means difficult and dangerous operations were brought in his hands to a happy issue where more rapid but rougher surgeons failed. Moynihan saw also the great value of careful preparation before operation so as to bring the patients into the most favourable condition, and to this end he devoted as much atten. tion as to the operation itself. To use his own words, he raised his surgery to the sanctity of a sacrament.

But Moynihan was more than a deft user of his hands. He was intensely interested in the scientific side of his profession and made considerable contributions to clinical science which of themselves entitle him to fame and to rank with the Masters of Medicine. The most important of these are in connexion with diseases of the duodenum, stomach and gall bladder. The recognition of duodenal ulcer and its successful treatment we owe to Moynihan. By skilfully correlating the symptoms as related by patients and observations made in the operating theatre, he drew a clinical picture of the disease by which it can now be recognized with ease and accuracy.

The operation of gastrectomy for gastric ulcer received a great impetus in the hands of Moynihan. He picked up the idea, probably, from Polya, but he modified and improved it and, what is more, taught other surgeons to do it too. Other important contributions were made on diseases of the spleen, pancreas and gall bladder, and again he showed that the morbid condition was characterized by a definite clinical picture.

By these means Moynihan was led to inculcate a doctrine, the truth of which is being but slowly admitted, that there is a pathology of the living, distinct from the autopsy chamber. He held that the beginnings of disease processes should be studied while patients are yet alive, and that the best place to study these is the operating theatre, which he termed his laboratory.

Associated with this technical excellency was a power of organizing ability. Many years ago Moynihan realized that in order to raise the standard of surgery throughout Great Britain-and this ideal was very near his heart-it was essential not only to have a high individual standard, but also to create a free intercommunication and a comradeship between surgeons. He described these ideas in a letter written only last May. $\mathrm{He}$ writes :

"In my early days I was struck by the lack of cohesion among members of my profession. Surgeons in one town knew little or nothing of surgeons else. where. A surgeon from Manchester had never, so far as I could hear, visited an operation theatre in Leeds, nor had one ever been called in consultation. 
As a consequence it was not infrequent to listen to disparagement of one surgeon by another and jealousies openly expressed were too often heard. I thought this all wrong. If we were indeed members of a 'noble profession' as we most certainly were, then it was clearly an obligation upon us to speak well of one another. It seemed to me that if by any means we could be brought together, it would be a great advantage to us all and that we should then be made to realize that we were not competitors, one working against another, but comrades, each working with the others against the common enemy, disease."

The means that Moynihan took to accomplish his ideal were three. First came the foundation of the Provincial Chirurgical Club (since 1929 called the Moynihan Chirurgical Club). This body of surgeons met among themselves, visited each other's clinics as well as foreign cities. In this way the most important surgeons all over the world were visited, and Moynihan may be regarded as the finest medical ambassador England ever had. The second method was the establishment of the British Journal of Surgery, which under his chairmanship reached the proud position of the premier surgical journal. The third means and the most important, and one in which Moynihan took a prominent part, was the foundation of the Association of the Surgeons of Great Britain and Ireland. This has proved a great success and drawn together surgeons from all over the country, raised the standard of British surgery and removed the reproach of "lack of cohesion" among members of the profession.

One of the most important works of Moynihan's life and one of which he did not live to see the full fruits was the introduction of the study of experimental surgery. Moynihan saw that if surgery is to continue active and progressive, an intensive and direct study must be made of the many problems which confront the surgeon. During his time as president of the Royal College of Surgeons, he devoted time and energy to securing surgical research scholarships and laboratory accommodation where young men entering on the surgical profession might be trained in methods of research. His efforts were rewarded, and a flourishing school of this new science is growing up, the importance of which it is hard to predict.

Moynihan's life may be described as a success, a victorious success, and the world is the richer for his being.

G. E. G.

\section{Mr. E. R. Deacon, O.B.E.}

WE regret to record the death of Mr. Edgar Reginald Deacon on August 29. It may be recalled that during the early months of the Great War there was a serious shortage of high explosives ; in particular, the supply of T.N.T. (trinitrotoluene) available was totally inadequate to meet the enormous requirements. It was early in 1915 that Deacon, whose province at the Research Department, Woolwich, had been the study of high-explosive munitions, made the suggestion that by mixing the available T.N.T. with ammonium nitrate it could be made to go much farther without loss of efficiency, a fact which he demonstrated experimentally. At the outset he suggested the mixture of equal weights of these materials, this mixture having the advantage that it could be filled into shell by casting in a manner similar to that hitherto used for lyddite. Within two months he had worked out the more difficult problem of preparing and filling a mixture of 80 parts of ammonium nitrate and 20 of T.N.T., which contained too much ammonium nitrate to be cast. This advance made it possible to fill five times the number of shell hitherto possible with a given weight of T.N.T.

The importance of these suggestions was immediately recognized by his chief, Dr. (now Sir) Robert Robertson, who took steps to develop these mixtures further and brought them to the notice of the Ordnance Committee and Lord Moulton. In this way, birth was given to that important series of explosives later known as the amatols. Rapid expansion of the use of amatol followed in the national filling factories under the Ministry of Munitions, and many individuals contributed with great skill and ingenuity in furthering its successful application. It was used not only for shell but also for other munitions such as bombs, mines and torpedoes, and it has been estimated that no less than 600,000 tons were used by the British Services during the War.

The importance of the introduction of amatol is indicated by a speech made by Lord Moulton in 1917 in which he referred to two inventions brought forward by the Research Department, 40/60 and 80/20 amatol. By means of these he was enabled to meet his obligations, especially with $80 / 20$, which effected such a great saving in the use of T.N.T. He recalled the advocacy of the Research Department of this explosive, which he considered to be "the greatest single thing in importance in the supply of that wealth of munitions that has enabled our armies to expend shell to an unlimited extent".

Edgar Reginald Deacon was born in 1881 at Frome, educated at Sexey's School, Bruton, Somerset, and later studied at the Finsbury Technical College. For some time he held appointments as assistant to the late Mr. Chaston Chapman and as assistant chemist at the Clinical Research Association. In 1902 he joined the staff of the recently formed Experimental Establishment (now Research Department) at the Royal Arsenal, Woolwich, in which he remained until his death.

Deacon devoted many years to the study of highexplosive munitions and for more than twenty years was head of the high-explosives branch of the Directorate of Explosives Research. He was elected fellow of the Institute of Chemistry in 1917 and awarded the O.B.E. in 1918.

Deacon was highly original and full of resource. and many important improvements in the efficiency and safety of munitions are due to his work. The Fighting Services have lost a most valuable servant. To quote from a letter received from another Govern. ment Department : "All who had official dealings with Mr. Deacon will gratefully remember his wide knowledge, wise counsel and willing helpfulness." 